\title{
Reversible Umbilical Cord Occlusion: Effects on Thermogenesis In Utero
}

\author{
TANIA R. GUNN, KAREN T. BALL, AND PETER D. GLUCKMAN \\ Developmental Physiology Laboratory, Department of Paediatrics, School of Medicine, University of Auckland, \\ Auckland, New Zealand
}

\begin{abstract}
The initiation of thermogenesis at birth is an important adaptation for survival. We examined the sequential effects of cooling, increased oxygenation, and repeated episodes of umbilical cord occlusion on nonshivering thermogenesis in six fetal sheep at 139 to $145 \mathrm{~d}$ of gestation. The fetal sheep were cooled by circulating cold water through a coil placed around the trunk for $4 \mathrm{~h}$. The fetal core temperature fell $2.47 \pm 0.24^{\circ} \mathrm{C}$ in the first $60 \mathrm{~min}$ of cooling with minimal changes in plasma FFA and glycerol levels. After fetal arterial $\mathrm{O}_{2}$ tension was increased above $6.65 \mathrm{kPa}$ by ventilation, fetal temperature and thermogenic indices rose significantly in $60 \mathrm{~min}$. After occlusion of the umbilical cord by a reversible occluder cuff, plasma FFA levels rapidly increased to $635 \pm 69 \mu \mathrm{Eq} / \mathrm{L}(p<0.005)$ by $30 \mathrm{~min}$, fetal temperature increased a further $0.96 \pm 0.20^{\circ} \mathrm{C}$ $(p<0.001)$ and fetal $\mathrm{O}_{2}$ consumption peaked at $25.3 \pm$ $4.9 \mathrm{~mL} \cdot \mathrm{min}^{-1} \cdot \mathrm{kg}^{-1}$. Release of cord occlusion caused a rapid fall in FFA to $149 \pm 23 \mu \mathrm{Eq} / \mathrm{L}(p<0.005)$ and a fall in fetal core temperature of $0.90 \pm 0.13^{\circ} \mathrm{C}(p<0.001)$ in $30 \mathrm{~min}$. After irreversibly snaring the umbilical cord, the plasma FFA rose to $611 \pm 83 \mu \mathrm{Eq} / \mathrm{L}(p<0.005)$ and the fetal temperature rose $0.78 \pm 0.09^{\circ} \mathrm{C}(p<0.02)$. The effects on thermogenesis of interrupting and reestablishing placental flow are rapid and reversible and suggest the presence of placental inhibitors of brown adipose tissue thermogenesis. (Pediatr Res 30: 513-517, 1991)
\end{abstract}

Abbreviations

$\mathrm{T}_{3}, 3,5,3^{\prime}$ triiodothyronine

A rapid fall in environmental temperature accompanies the transition from intrauterine to extrauterine existence, and effective thermogenesis is essential to neonatal adaptation. Studies on temperature regulation have shown the importance of thermal homeostasis in reducing the mortality rate of low birth weight infants. The mortality in preterm infants subjected to cold stress is dependent upon the degree and duration of hypothermia (1, 2).

The demand for heat production is often maximal at the moment of birth, and the brown adipose tissue thermogenic response to chilling in newborn infants and precocial species such as the lamb is mediated by the sympathetic nervous system. Norepinephrine may increase oxygen consumption and heat production more than 3 -fold $(3,4)$. The mammalian fetal environment is relatively thermostable, and the fetus does not appear to regulate its temperature independently of the mother (5). We

Received October 31, 1990; accepted July 22, 1991.

Correspondence: Professor Tania Gunn, Developmental Physiology Laboratory, Department of Paediatrics, School of Medicine, University of Auckland, Auckland, New Zealand.

Supported by the Medical Research Council of New Zealand. have shown in previous studies of the fetal sheep that cooling the amniotic fluid by means of a coil placed around the fetal trunk fails to provoke nonshivering thermogenesis (6). However, shivering and appropriate cardiovascular (7) and endocrine responses including elevations of plasma catecholamines (8), thyrotropin (9), and cortisol (6) are stimulated by cooling in utero as early as $110 \mathrm{~d}$ gestation. Oxygenation of the cooled fetal sheep by ventilation in utero caused only a limited thermogenic response, whereas subsequent umbilical cord occlusion was followed by substantial nonshivering thermogenesis associated with increased oxygen consumption and heat production (10). One explanation of these findings was that the placenta produced factors that inhibited nonshivering thermogenesis in utero. The aim of this study was to further investigate this hypothesis.

\section{MATERIALS AND METHODS}

Surgical preparation. Operations were performed on six pregnant Romney ewes at 139-145 d of gestation under halothane$\mathrm{O}_{2}$ anesthesia using aseptic techniques as previously described (11). Polyvinyl catheters were implanted into the fetal carotid artery, jugular vein, amniotic sac, and also into the maternal femoral artery and tarsal vein. Calibrated thermistors were placed in the fetal esophagus and maternal vena cava to record core body temperatures. Another thermal thermistor was placed near a fetal kidney to measure perirenal brown fat temperatures, because this is one of the major sites of brown adipose tissue in the lamb (12). A 5-m coil of plastic tubing was placed around the fetal thorax and neck. A loop of umbilical tape was placed loosely around the umbilical cord, and in addition a reversible cord occluder was placed around the umbilical cord. A tracheal cannula ( $6 \mathrm{~mm}$ outer diameter) was inserted and connected to a length of tubing ( $7 \mathrm{~mm}$ inner diameter; dead space $15 \mathrm{~mL}$ ) to later ventilate the fetus (10). The breathing tube, thermistor leads, afferent and efferent arms of the cooling coil, snare, reversible cord occluder, and catheters were exteriorized through an incision in the maternal flank. After the operation the ewes were housed in a metabolic cage at a constant temperature of $16^{\circ} \mathrm{C}$ and $50 \%$ relative humidity and given free access to water, hay supplemented by alfalfa, corn, and sheep nuts. The animals were studied $24 \mathrm{~h}$ after surgery.

Experimental procedures. After suitable amplification, fetal arterial pressure, heart rate, tracheal pressure, and amniotic pressure were displayed on a polygraph. Fetal and maternal temperature measurements were made continuously using a fivechannel, microprocessor-controlled, amplified transducer unit with a resolution of $0.01{ }^{\circ} \mathrm{C}(11)$.

The effects of reversible cord occlusion. The following day, six fetal sheep were studied after a $30-\mathrm{min}$ control period. Cooling was begun by passing cold water $\left(14-19^{\circ} \mathrm{C}\right)$ through the coil at a rate of 160 to $290 \mathrm{~mL} / \mathrm{min}$, adjusted so that the fetal core temperature fell $2-3^{\circ} \mathrm{C}$ during the first hour of cooling (5). One h later, fluid was drained from the lungs and the tracheal tube connected to ventilate the lungs with $\mathrm{O}_{2}$ from a closed rebreath- 
ing circuit. This consisted of a respiratory pump (model 607; Harvard Apparatus Co., Inc., S. Natick, MA), a liter spirometer, one-way valving, and a $\mathrm{CO}_{2}$ absorber. The ventilator settings were adjusted to maintain fetal arterial $\mathrm{PCO}_{2}$ in the range 5.3$7.3 \mathrm{kPa}\left(40-55\right.$ torr) and a $\mathrm{PO}_{2}$ above $6.7 \mathrm{kPa}$ (50 torr) throughout the rest of the experiment. After $1 \mathrm{~h}$ of ventilation, the reversible umbilical cord occluder was inflated by injecting a measured volume of saline. After $30 \mathrm{~min}$ of occlusion, the saline was withdrawn, thus reestablishing umbilical flow. Ventilation and cooling were then continued for an additional $30 \mathrm{~min}$. To conclude the experiment, the snare around the umbilical cord was pulled tight, thus causing irreversible cord occlusion; responses were followed for an additional $1 \mathrm{~h}$ in isolation from the placenta.

Fetal carotid arterial blood samples $(2.8 \mathrm{~mL})$ were collected anaerobically every $15 \mathrm{~min}$ throughout the experiment and analyzed promptly for $\mathrm{pH}$ and blood gases. The plasma was then removed after centrifugation and stored at $-20^{\circ} \mathrm{C}$ for later analysis.

After completion of the experiment, the ewe and fetus were killed with an overdose of barbiturate. The closed rebreathing circuit was checked for leaks. The location of the thermistors was verified, as was the complete occlusion of the umbilical cord. The fetus was weighed to the nearest gram. The thermistors were recalibrated to establish that their characteristics had not changed during implantation.

These studies were approved by the Animal Ethics Committee of the Auckland Medical School.

Analytical procedures. $\mathrm{PO}_{2}, \mathrm{PCO}_{2}$, and $\mathrm{pH}$ were measured at $39^{\circ} \mathrm{C}$ using microelectrodes (ABL330; Radiometer, Copenhagen, Denmark). Observed values were corrected to the body temperatures of the fetus (13). Plasma FFA were determined using the colorimetric method of Falholt et al. (14). Palmitic acid was used as the standard, and a sample size of $0.1 \mathrm{~mL}$ was used to increase sensitivity. Glycerol was analyzed after enzymatic conversion with glycerokinase by using the method of Pinter et al. (15). The within- and between-assay coefficients of variation were 2.2 and $4.1 \%$ for the glycerol assay and 9.0 and $14.1 \%$ for the FFA assay, respectively. The volume change in the spirometer with time was used as an index of $\mathrm{O}_{2}$ uptake rate by the lungs. Slopes were averaged, the time to use $1 \mathrm{~L}$ was measured, and oxygen uptake was expressed as $\mathrm{mL}$ of $\mathrm{O}_{2}$ standard temperature and pressure $\mathrm{dry} / \mathrm{min} / \mathrm{kg}$ of fetal weight. Before cord occlusion, pulmonary oxygen uptake included use by placental tissue as well as fetal tissue. After cord occlusion, pulmonary oxygen uptake became equal to the rate of oxygen consumption by the fetus alone.

Data analysis. Results are shown as mean \pm SEM. Statistical comparisons were made by two-way analysis of variance with phase and time from the initiation of each intervention as repeated measures, and between the means at the start of each episode of the study and experimental values at the end of that episode using the paired $t$ test. Repetitive measures to the control value were not examined.

\section{RESULTS}

Effects of reversible cord occlusion. Six fetuses with a gestation of $141 \pm 1 \mathrm{~d}$ and weight of $4125 \pm 708 \mathrm{~g}$ were studied.

Effects of cooling. After $60 \mathrm{~min}$ of cooling the fetal environment, the fall in fetal core temperature was $2.47 \pm 0.24^{\circ} \mathrm{C}$ and the maternal temperature fell $0.08 \pm 0.06^{\circ} \mathrm{C}$ (Fig. 1). The fetal maternal temperature gradient was thus reversed. The effects of cooling on fetal blood gases and $\mathrm{pH}$ are shown in Table 1 . The fetuses became hypoxemic during cooling as previously reported (5). Plasma FFA and glycerol levels showed no significant response to $60 \mathrm{~min}$ of cooling. Plasma glucose rose from $0.62 \pm$ 0.03 to $1.37 \pm 0.09 \mathrm{mmol} / \mathrm{L}(p<0.001)$ and plasma lactate rose from $3.3 \pm 0.4$ to $7.9 \pm 0.4 \mathrm{mmol} / \mathrm{L}(p<0.001)$.

Ventilation with oxygen. Effective ventilation with oxygen was typically achieved within $13 \mathrm{~min}$, and the fetal arterial $\mathrm{PO}_{2}$ was maintained above $6.65 \mathrm{kPa}$ for the rest of the study (Table 1). The rate of cooling continued unchanged from that achieved during the preventilation phase, yet after $60 \mathrm{~min}$ of oxygenation the fetal core temperature had risen $0.92 \pm 0.24^{\circ} \mathrm{C}(p<0.02)$. The fetal plasma FFA and glycerol concentrations also rose from $78 \pm 16$ to $183 \pm 29 \mu \mathrm{Eq} / \mathrm{L}(p<0.01)$ and from $204 \pm 19$ to $370 \pm 41 \mathrm{mM} / \mathrm{L}(p<0.02)$, respectively, from the values after $60 \mathrm{~min}$ of cooling (Fig. 2). The plasma glucose and lactate concentrations did not show any further changes.

Umbilical cord occlusion. After $30 \mathrm{~min}$ of occlusion of the umbilical cord, there was a rapid rise in fetal core temperature of $0.96 \pm 0.20^{\circ} \mathrm{C}(p<0.001)$ and plasma FFA and glycerol concentrations to $635 \pm 69 \mu \mathrm{Eq} / \mathrm{L}(p<0.005)$ and $640 \pm 51$ $\mathrm{mM} / \mathrm{L}(p<0.01)$, respectively, from values at the end of the oxygenated period (Fig. 2). The oxygen consumption of the fetus peaked after occlusion at $25.3 \pm 4.9 \mathrm{~mL} \cdot \mathrm{min}^{-1} \cdot \mathrm{kg}^{-1}$. Plasma

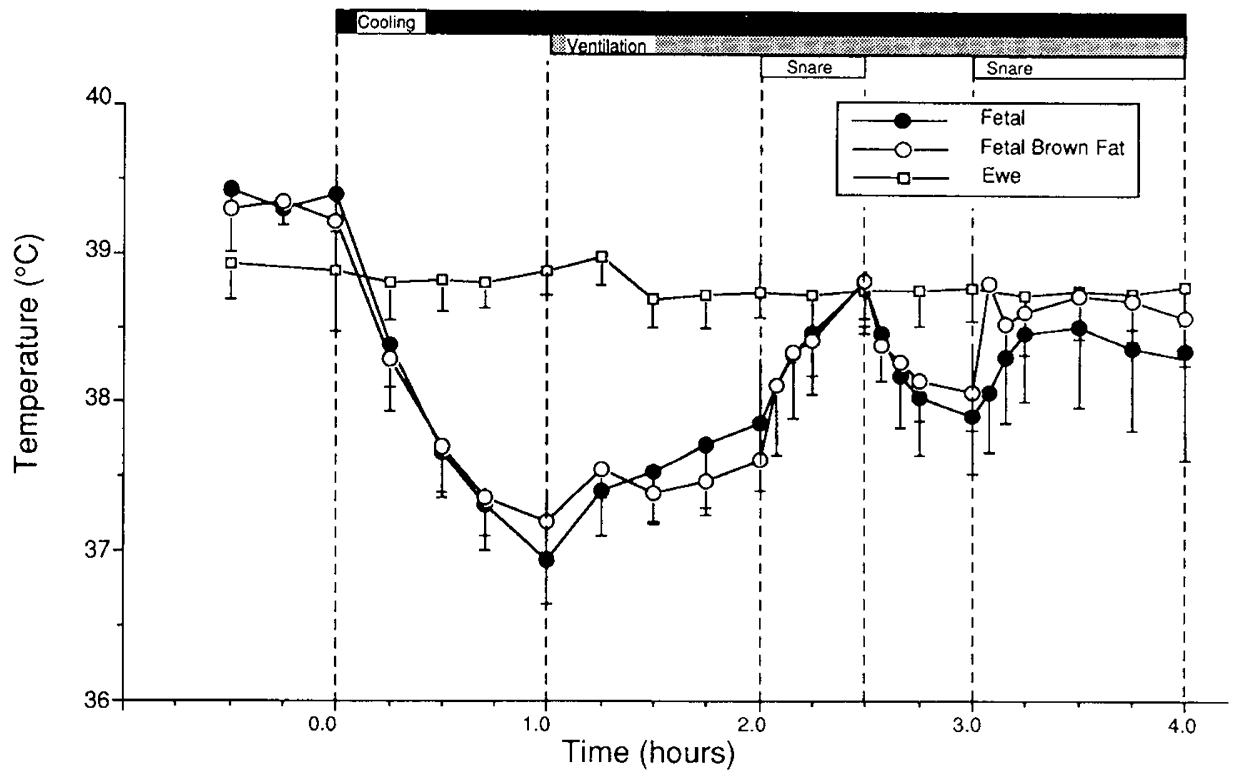

Fig. 1. Time course of responses of fetal core and brown fat temperatures and ewe temperatures during cooling, oxygenation, and two episodes of umbilical cord occlusion (Snare). Means and SEM for six fetal sheep are shown. $\bullet$, Fetal core temperature; $O$, fetal brown fat temperature. $\square$. ewe temperature. 
Table 1. Changes in fetal arterial blood gases and $\mathrm{pH}$ in response to cooling, ventilation with oxygen, and reversible and then irreversible umbilical cord occlusion*

\begin{tabular}{lcccc}
\hline & $\begin{array}{c}\text { Time } \\
(\mathrm{min})\end{array}$ & $\mathrm{PaO}_{2}$ & $\mathrm{PaCO}_{2}$ & $\mathrm{pH}$ \\
\hline Control & -30 & $2.99 \pm 0.16$ & $7.55 \pm 0.31$ & $7.41 \pm 0.01$ \\
& 0 & $2.83 \pm 0.09$ & $7.38 \pm 0.39$ & $7.42 \pm 0.01$ \\
Cooling & +30 & $2.27 \pm 0.07$ & $7.54 \pm 0.23$ & $7.37 \pm 0.01$ \\
& +60 & $2.17 \pm 0.07$ & $7.29 \pm 0.31$ & $7.36 \pm 0.01$ \\
Ventilation & +30 & $6.93 \pm 0.72$ & $8.83 \pm 0.73$ & $7.26 \pm 0.04$ \\
& +60 & $7.14 \pm 0.64$ & $7.73 \pm 0.35$ & $7.33 \pm 0.03$ \\
Snare cord & +15 & $7.34 \pm 0.94$ & $9.03 \pm 0.55$ & $7.30 \pm 0.04$ \\
& +30 & $7.67 \pm 1.26$ & $8.05 \pm 0.88$ & $7.36 \pm 0.04$ \\
Release snare & +15 & $7.78 \pm 0.69$ & $7.01 \pm 0.45$ & $7.37 \pm 0.03$ \\
& +30 & $7.30 \pm 1.05$ & $7.46 \pm 0.65$ & $7.35 \pm 0.03$ \\
Snare cord & +15 & $6.48 \pm 0.52$ & $8.06 \pm 0.35$ & $7.33 \pm 0.02$ \\
& +30 & $6.69 \pm 1.36$ & $6.18 \pm 0.45$ & $7.44 \pm 0.03$ \\
& +60 & $7.05 \pm 1.26$ & $5.61 \pm 0.43$ & $7.48 \pm 0.03$ \\
& +90 & $7.22 \pm 0.92$ & $6.49 \pm 0.59$ & $7.43 \pm 0.05$ \\
\hline
\end{tabular}

$* n=6$, mean \pm SEM. $\mathrm{PaO}_{2}$, arterial $\mathrm{O}_{2}$ tension; $\mathrm{PaCO}_{2}$, arterial $\mathrm{CO}_{2}$ tension.

glucose concentration was $1.73 \pm 0.29 \mathrm{mmol} / \mathrm{L}$, and lactate fell to $5.6 \pm 0.6 \mathrm{mmol} / \mathrm{L}(p<0.05)$ by $30 \mathrm{~min}$.

Release of umbilical cord occlusion. Within $30 \mathrm{~min}$ of the reestablishment of umbilical cord circulation by the release of the umbilical cord occluder, the fetal core temperature fell 0.90 $\pm 0.13^{\circ} \mathrm{C}(p<0.001)$ (Fig. 1). Plasma FFA concentration fell to $149 \pm 23 \mu \mathrm{Eq} / \mathrm{L}(p<0.005)$, and plasma glycerol also showed a decline to $574 \pm 114 \mathrm{mM} / \mathrm{L}$ (NS) (Fig. 2). The plasma glucose level was $1.70 \pm 0.26 \mathrm{mmol} / \mathrm{L}$, and lactate rose $(p<0.04)$ to 7.9 $\pm 1.1 \mathrm{mmol} / \mathrm{L}$

Irreversible umbilical cord occlusion. When the umbilical cord circulation was then occluded irreversibly by tightening the tape around the umbilical cord, thermogenic responses were again rapidly initiated. Within $30 \mathrm{~min}$ the fetal core temperature rose $0.78 \pm 0.09^{\circ} \mathrm{C}(p<0.02)$. There were no significant changes in maternal temperatures throughout the study (Fig. 1). The plasma FFA and glycerol concentration increased to $611 \pm 83 \mu \mathrm{Eq} / \mathrm{L}(p$ $<0.005$ ) and $689 \pm 109 \mathrm{mM} / \mathrm{L}$, respectively, compared with the values after the release of cord occlusion (Fig. 2). These FFA and glycerol levels were 3 - to 10 -fold greater than mean control values and remained elevated for the remainder of the study. The oxygen consumption was $24.6 \pm 4.7 \mathrm{~mL} \cdot \mathrm{min}^{-1} \cdot \mathrm{kg}^{-1} 30 \mathrm{~min}$ after irreversible cord occlusion. The plasma glucose level was $1.53 \pm 0.45 \mathrm{mmol} / \mathrm{L}$ and lactate fell to $6.2 \pm 1.1 \mathrm{mmol} / \mathrm{L}(p<$ $0.03)$.

\section{DISCUSSION}

Nonshivering thermogenesis begins shortly after birth and is very well developed in the postnatal term lamb (4). Even preterm lambs delivered after glucocorticoid induction of premature parturition have the ability, although reduced, for nonshivering thermogenesis (16). In contrast, cooling the near-term fetal lamb in utero caused only very limited changes in FFA and glycerol levels in this and previous studies $(6,10,17)$. Similarly, an infusion of norepinephrine in the fetal lamb caused only a minor increase in lipolysis (18) and oxygen consumption (from 8.2 to $10.2 \mathrm{~mL} / \mathrm{kg} / \mathrm{min}$ ) (19), but no rise in fetal temperature (17). The remarkable capacity for thermogenesis of brown adipose tissue depends on the amount of uncoupling protein (thermogenin); this has been identified in the mitrochondria of the brown fat of human infants (20) and, in the fetal calf and lamb, is present by the beginning of the $3 \mathrm{rd}$ trimester (21).

An increase in oxygen delivery to brown adipose tissue is required for nonshivering thermogenesis, and an increased blood flow to brown fat occurs during fetal cooling (22). With the increased blood oxygen tension that followed ventilation with oxygen in the fetal lamb, the rise in plasma FFA and glycerol was modest in this as in our previous studies $(10,23)$. Our observations suggest that separation from the placenta is necessary for maximal nonshivering thermogenesis. Umbilical cord occlusion was the signal for a rapid increase in thermogenesis, whereas the release of cord occlusion was followed by an equally

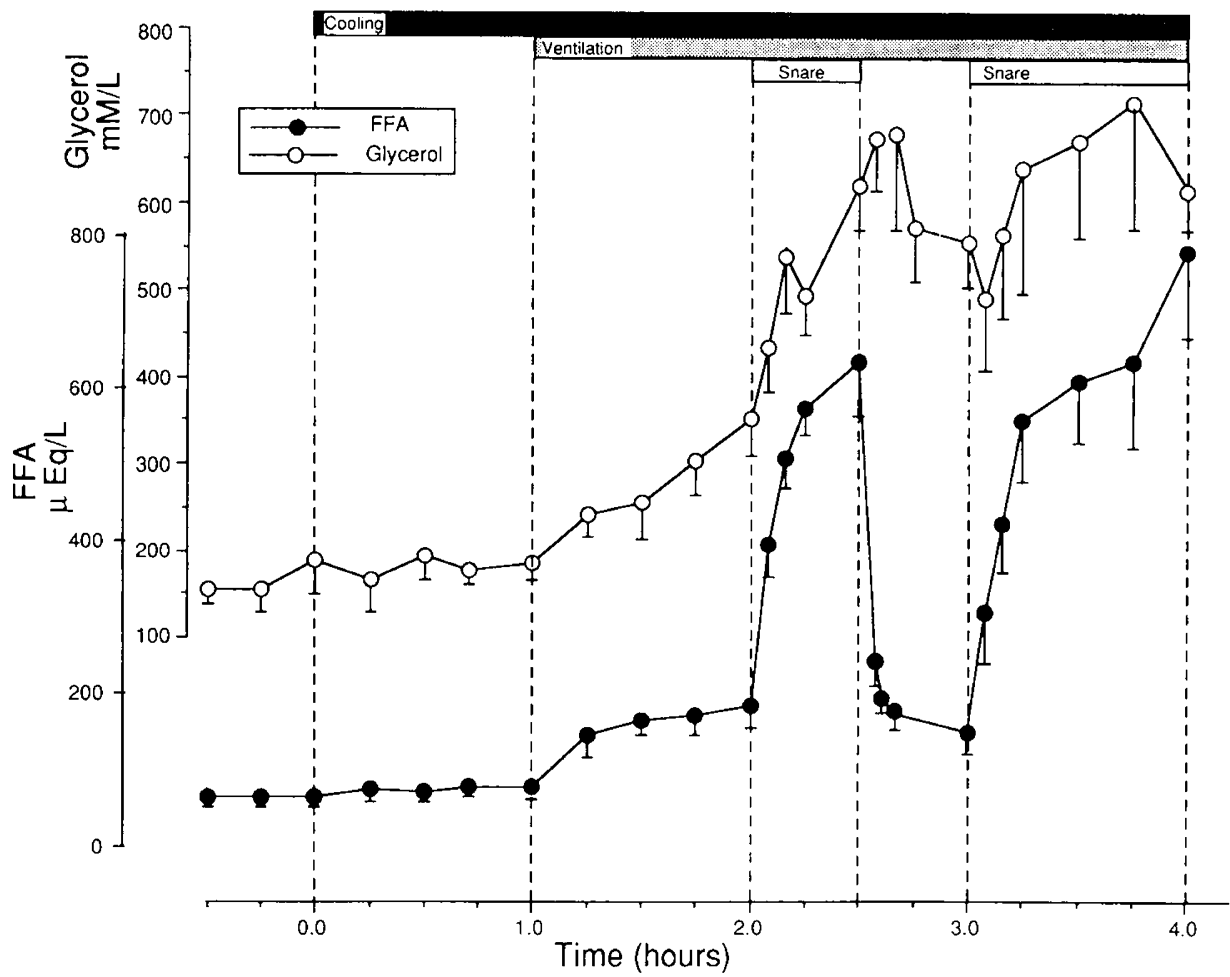

Fig. 2. Time course of responses of fetal plasma FFA and glycerol concentrations during cooling, ventilation with oxygen, and two episodes of umbilical cord occlusion (Snare). Means and SEM for six fetal sheep are shown. $\bullet$, FFA concentration; $\bigcirc$, glycerol concentration. 
rapid fall in thermogenesis. Umbilical cord occlusion is not associated with a change in the metabolic clearance rate of glycerol (24) or FFA (Power GG, personal communication), so the increase in these lipolytic indices that we observed after cord occlusion was not due to kinetic changes.

Under basal conditions, $85 \%$ of the heat transfer from the fetus to the ewe occurs across the placenta (25). With the interruption of the placental circulation, the fetus is only able to lose heat through the uterus to the ewe and through the abdominal wall and then only if the temperature gradient is from fetus to ewe. In our study, as a result of passing cold water through a coil encircling the fetal thorax in the amniotic fluid, the fetal core temperature was below that of the ewe before umbilical cord occlusion, so the balance of heat transfer under these study conditions would be from the ewe to the fetus. Interruption of the placental circulation would stop this transfer of heat to the fetus; thus, the rapid rise seen in fetal temperature after umbilical cord occlusion must have been due to the initiation of brown adipose tissue thermogenesis.

In the present study, after cord occlusion the increase in fetal temperature was both rapid and of large amplitude; plasma FFA and glycerol increased 3- to 10 -fold, and the fetal oxygen consumption peaked at $25.3 \pm 4.9 \mathrm{~mL} / \mathrm{min}^{-1} \cdot \mathrm{kg}^{-1}$. All of these indices of brown adipose tissue heat production fell rapidly when umbilical cord occlusion was released.

There are several possible explanations for the effects of separation from the placental circulation that we observed.

The neonatal surge in plasma $T_{3}$ has been suggested as the signal for the initiation of nonshivering thermogenesis by Fisher and Klein (1980) (26), and circulating $\mathrm{T}_{3}$ levels rise rapidly after cord snare in the lamb $(10,27)$. Thyroidectomy in midgestation resulted in the birth of profoundly hypothermic lambs that died (28). Thyroidectomy at $133 \mathrm{~d}$ gestation in fetal sheep was associated with reduced neonatal serum FFA levels and rectal temperatures (29). In contrast, acute thyroidectomy during delivery abolished the postnatal surge in plasma $T_{3}$ concentration, but there was no significant difference in oxygen consumption compared with controls (30). This may be due to the long half-life of thyroxine, which would allow intracellular conversion of thyroxine to $T_{3}$ to continue in the brown adipocyte. We have infused cooled, ventilated fetal lambs with a large dose of $\mathrm{T}_{3}$ for $30 \mathrm{~min}$, and this had no effect on the degree of nonshivering thermogenesis in the fetus (23). It appears that intracellular $\mathrm{T}_{3}$ is an essential prerequisite for neonatal thermogenesis, but the circulating $\Upsilon_{3}$ surge after delivery is not regulatory $(29,30)$.

Plasma catecholamine concentrations rise dramatically at birth in the human infant and lamb $(31,32)$. Catecholamines do not cross the placenta and in the fetal lamb increase after hypothermia (8), hypoxia (33), hemorrhage (34), labor (32), and umbilical cord cutting (35). The surge in catecholamine that occurs at birth is associated with a rise in plasma FFA levels. It has been suggested by Padbury et al. $(35,36)$ that this is the primary signal for the initiation of nonshivering thermogenesis. In previous studies $(8,23)$, the initial surge in plasma catecholamines after cooling without ventilation or cord snare was not accompanied by nonshivering thermogenesis. If brown adipose tissue responded in utero to the huge increases in circulating catecholamines that follow hypoxic stimuli (33) or labor (32) with nonshivering thermogenesis, the resulting increase in oxygen demand and heat production would jeopardize fetal survival.

We must therefore consider the possibility of a factor or factors secreted by the placenta that can inhibit nonshivering thermogenesis in utero in the presence of elevated circulating catecholamines. This placental inhibitor must be withdrawn for the initiation of maximal nonshivering thermogenesis and must therefore have a short half-life, inasmuch as nonshivering thermogenesis is rapidly initiated after umbilical cord occlusion and is equally rapidly suppressed when the cord occlusion is released. The presence of such inhibitor(s) would be of benefit to neonatal adaptation.
There are many possible placental inhibitors. For example, substances such as prostaglandin $E_{2}$ are antilipolytic (37) and are produced by the placenta (38). Another possible placental inhibitor is adenosine, which is an important regulator of metabolism in brown adipose tissue (39). Adenosine is found in perfusates of human placenta (40). Both fetal plasma prostaglandin $E_{2}(41)$ and adenosine (42) have been shown to fall after umbilical cord occlusion. The withdrawal of an inhibitor(s) at birth by separation from the placenta would allow the rapid initiation of nonshivering thermogenesis in the newborn in response to sympathetic stimulation.

\section{REFERENCES}

1. Silverman WA, Fertig JW, Berger AP 1958 The influence of the thermal environment on the survival of newly born premature infants. Pediatrics 22:876-885

2. Bruck K 1961 Temperature regulation in the newborn infant. Biol Neonate 3:65-119

3. Karlsberg P, Moore RE, Oliver TK 1965 Thermogenic and cardiovascular responses of the newborn baby to noradrenaline. Acta Paediatr Scand 54:225-238

4. Alexander G, Williams D 1968 Shivering and nonshivering thermogenesis during summit metabolism in young lambs. J Physiol (Lond) 198:251-276

5. Gunn TR, Gluckman PD 1983 The development of temperature regulation in the fetal lamb. J Dev Physiol 5:167-179

6. Gunn TR, Butler J, Gluckman PD 1986 Metabolic and hormonal responses to cooling the fetal sheep in utero. J Dev Physiol 8:55-66

7. Gluckman PD, Gunn TR, Johnston BM 1983 The effect of cooling on breathing \& shivering in unanaesthetized fetal lambs in utero. J Physiol (Lond) 343:495-506

8. Gunn TR, Johnston BM, Iwamoto HS, Fraser M, Nicholls MG, Gluckman PD 1985 Haemodynamic and catecholamine responses to hypothermia in the fetal sheep in utero. J Dev Physiol 7:241-249

9. Fraser M, Gunn TR. Butler JH, Johnston BM, Gluckman PD 1985 Circulating thyrotropin (TSH) in the ovine fetus: evidence for pulsatile release and the effects of hypothermia in utero. Pediatr Res 19:208-212

10. Power GG, Gunn TR, Johnston BM, Gluckman PD 1987 Oxygen supply and the placenta limit thermogenic response in fetal sheep. J Appl Physiol 63:1896-1901

11. Gluckman PD, Gunn TR, Johnston BM, Quinn JP 1984 Manipulation of the temperature of the fetal lamb in utero. In: Nathanielsz PW (ed) Animal Models in Fetal Physiology III. Perinatology Press, Ithaca, NY, pp 37-56

12. Alexander $G$ 1981 Development of brown fat in the sheep fetus: preparation for neonatal thermogenesis. Proc Aust Physiol Pharmacol Soc 12:31-35

13. Severinghaus JW 1966 Blood gas calculator. J Appl Physiol 21:1108-1116

14. Falholt K, Lund B, Falholt W 1973 An easy colorimetric micromethod for routine determination of free fatty acid in plasma. Clin Chim Acta 46:105111

15. Pinter JK, Hayashi JA, Watson JA 1967 Enzymatic assay of glycerol, dihydroxyacetone and glyceraldehyde. Arch Biochem Biophy 121:404-414

16. Alexander G, Nichols D, Thorburn G 1973 Foetal and neonatal physiology. In: Proceedings of the Sir Joseph Barcroft Centenary Symposium. Cambridge University Press, Cambridge, UK, pp 410-417

17. Hodgkin DD, Gilbert RD. Power GG 1988 In vivo brown fat response to hypothermia and epinephrine in the ovine fetus. J Dev Physiol 10:383-391

18. James E, Meschia G, Battaglia FC 1971 A-V differences of free fatty acids and glycerol in the ovine umbilical circulation. Proc Soc Exp Biol Med 138:823826

19. Lorijn RHW, Longo LD 1980 Norepinephrine elevation in the fetal lamb: oxygen consumption and cardiac output. Am J Physiol 239:R115-R122

20. Lean MEJ, James WPT, Jennings G, Trayhurn P 1986 Brown adipose tissue uncoupling protein content in human infants, children and adults. Clin Sci 71:291-297

21. Casteilla L, Champigny O, Bouilland F, Robelin J, Ricquier D 1989 Sequential changes in the expression of mitochondrial protein mRNA during the development of brown adipose tissue in bovine and ovine species. Biochem J 257:655-671

22. Kawamura T, Gilbert RD, Power GG 1986 Effect of cooling and heating on the regional distribution of blood flow in fetal sheep. J Dev Physiol 8:11-21

23. Power GG, Gunn TR, Johnston BM, Nichols G, Gluckman PD 1989 Umbilical cord occlusion but not increased plasma $T_{3}$ or norepinephrine stimulate brown adipose tissue thermogenesis in the fetal sheep. J Dev Physiol 11:171-
177

24. Power GG, Ball KT, Asakura H, Gluckman PD 1990 Rate of disappearance of glycerol from plasma of fetal and newborn sheep. J Appl Physiol 68:271274

25. Gilbert RD, Schroder H, Kawamura T, Dale PS, Power GG 1985 Heat transfer pathways between the fetal lamb and ewe. J Appl Physiol 59:634-638

26. Fisher DA, Klein AH 1980 The ontogenesis of thyroid function and its relationship to neonatal thermogenesis. In: Tulchinshy D, Ryan KJ (eds) Maternal Fetal Endocrinology. Saunders, Philadelphia, pp 281-293

27. Sack J, Beaudry M, De Lamater PV, Oh W, Fisher DA 1976 Umbilical cord cutting triggers hypertriiodothyroninemia and nonshivering thermogenesis in the newborn lamb. Pediatr Res 10:169-175 
28. Thorburn GD, Hopkins PS 1973 Thyroid function in the foetal lamb. In: Comline KS, Cross KW, Dawes GS, Nathanielsz PW (eds) Foetal and Neonatal Physiology. Cambridge University Press, Cambridge, UK, pp 488 507

29. Polk DH, Callegari CC. Newnham J, Padbury JF, Reviczky A, Fisher DA, Klein AH 1987 Effect of fetal thyroidectomy on newborn thermogenesis in lambs. Pediatr Res 21:453-457

30. Breall JA, Rudolph AM, Heymann MA 1984 Role of thyroid hormone in postnatal and metabolic adjustments. J Clin Invest 73:1418-1424

31. Lagercrantz H, Bistoletti P 1973 Catecholamine release in the newborn infant at birth. Pediatr Res 11:889-893

32. Eliot RJ, Klein AH, Glatz TH, Nathanielsz PW, Fisher DA 1981 Plasma norepinephrine, cpinephrine and dopamine concentrations in maternal and fetal sheep during spontaneous parturition and in premature sheep during cortisol-induced parturition. Endocrinology 108:1678-1682

33. Jones CT, Robinson RD 1975 Plasma catecholamines in foetal and adult sheep. J Physiol (Lond) 248:15-33

34. Jones CM, Rose JC, Kelly RT, Hargrave BY 1985 Catecholamine responses in fetal lambs subjected to hemorrhage. Am J Obstet Gynecol 151:475-478

35. Padbury JF, Diakomanolis ES, Hobel CJ, Perelman A, Fisher DA 1981
Neonatal adaptation: sympatho-adrenal response to umbilical cord cutting. Pediatr Res 15:1483-1487

36. Padbury JF, Polk DH, Newnham JP, Lam RW 1985 Neonatal adaptation: greater sympathoadrenal response in preterm than full-term fetal shcep at birth. Am J Physiol 248:E443-E449

37. Steinberg.D, Vaughan M, Nestel PJ. Strand O, Bergstrom S 1964 Effects of the prostaglandins on hormone-induced mobilization of free fatty acids. J Clin Invest 43:1533-1537

38. Mitchell MD, Brunt J, Bibby J, Flint APF, Anderson ABM, Turnbull AC 1978 Prostaglandins in the human umbilical circulation at birth. $\mathrm{Br} \mathrm{J}$ Obstet Gynaecol 85:114-118

39. Szillat D, Bukowiecki L 1983 Control of brown adipose tissue lipolysis and respiration by adenosine. Am J Physiol 245:E555-E559

40. Slegel P, Kitagawa H, Maguire MH 1988 Determination of adenosine in feta perfusates of human placental cotyledons using fluorescence derivatization and reversed-phase high performance liquid chromatography. Anal Biochem and reversed-phicis

41. Lees DS, Choy P, Davi M, Caces R, Gibson D, Hasan SD, Cates D, Rigatto H 1989 Decrease in plasma prostaglandin $E_{2}$ is not essential for the establish ment of continuous breathing at birth in sheep. J Dev Physiol 12:145-151

42. Sawa R, Asakura H, Power GG 1991 Changes in plasma adenosine during simulated birth of fetal sheep. J Appl Physiol 70:1524-1528 